\title{
AN OVERVIEW OF GIANNI RODARI'S BOOKS IN TRANSLATION AROUND THE WORLD (2000-2020)
}

In Italy and abroad, 2020 marks the $100^{\text {th }}$ anniversary of Gianni Rodari's birth. Rodari remains one of the most famous Italian writers and poets for children: his fame in Italy started with his first published book of nursery rhymes, "Filastrocche in cielo e in terra" (Giulio Einaudi Publishing House, 1960). His affiliation with the Italian Communist Party made him well-known in countries where Communism thrived. Rodari became famous beyond his expectations in Russia before being canonized as a notable writer for children in his home country. In 1970, having been presented with the Hans Christian Andersen Award, Rodari earned the status of being the $6^{\text {th }}$ most translated Italian writer in the world, according to the UNESCO Index Translationum. This ensured worldwide visibility that spread the word for Rodari's work and it attracted the attention of translators who focused on linguistic creativity, such as puns and rhymes that continues to permeate the works of modern day children's literature.

This contribution aims to provide an updated overview of Rodari's books in translation around the world since 2000. A reliable source to trace translations before 2000 is Cerutti and Cicala's «Rodari, le storie tradotte» (2002) that came as a result of an international conference held in Omegna, Italy, in 2000. The book offers a list of translations of Rodari's most significant works, as well as contributions by his translators, who write about their experience with the intricate nature of his poetry, that often defies linguistic norms.

Claudia Alborghetti

Università Cattolica del Sacro Cuore,

Milan

claudia.alborghetti@unicatt.it 
The past few years have seen a substantial increase in the research of Rodari's works in translation into English, Polish, Russian, Albanian, Croatian, and Portuguese. Russia is among the most prolific countries to take part in both academic research on Rodari, as well as the continued translation of his works. Since 2000, two translators have worked with different publishing houses to bring new works by Rodari to the Russian reader: Mikhail Viesel and Irina Konstantinova. Mikhail Viesel has translated previously unknown works by Rodari, including the 2013 «Удивительная книга сказок и стихов Джанни Родари» (Fairy Tales for Christmas), «Гондола-призрак» (The Ghost Gondola), and «Коты города Рима» (Mr. Cat in Business) , in 2015 «Охотница Аталанта» (Atalanta), and in 2019, «Театр Джанни Родари» (The Theatre of Gianni Rodari). As for Irina Konstantinova, she has been familiar with Rodari's work since the 1970s. From 2000 onward, she has translated a variety of books spanning from novels to poetry, including the story on linguistic mistakes, «Какие бывают ошибки стихи и сказки» (The Book of Errors) in 2015, which she collaborated with Lev Tarasov. It is worth mentioning that in 2020 , the new book of poems, «Лето в комоде» (Summer in the Dresser), was translated by Tatyana Stamova.

Academic research in translation indicates that Rodari's work is still a source of inspiration today in an «intersemiotic cultural space» (theatre, films, cartoons) and is cited in school syllabi as an important writer in the $21^{\text {st }}$ century [De Florio 2019, 24], thus showing how the multifaceted creativity of Rodari can be adapted to different media to convey new meaning to the young public. This translation followed earlier works by Samuil Marshak and it marked the return to Rodari's poetry for children, after a long break marked by numerous translations and reprints of Rodari's prosaic novels. Rodari's work continues to be a source of inspiration in an "intersemiotic cultural space" (theatre, films, cartoons) and he is included into school syllabi as an important 21st century writer [De Florio 2019, 24]. It is evident that Rodari's multifaceted creativity can be adapted into different media, while conveying a new meaning for the young audience.

According to Ewa Nicewicz-Staszowska, Rodari became famous through his books on nursery rhymes in Socialist Poland after the Second World War. The translator, Janusz Minkiewicz, had already worked on the translation of Samuil Marshak's poetry and stated that in translating Rodari, he referred to Marshak's own translations of the Italian writer [Nicewicz-Staszowska, in print]. Rodari's translated poetry reappears in 2002 with the nursery rhymes on Pinocchio translated by Jarosław Mikołajewski, and later in 2014 with „Kocia gwiazda” (Mr. Cat 
in Business). Nicewicz-Staszowska concludes that Rodari in Poland is still renowned for his works in prose rather than his poetry; the novel "Cipollino" (Little Onion) was translated in 1954 by Zofia Ernst, one of the most prolific translators of Rodari. Between 2003 and 2008, Mikołajewski is seen as the most prolific translator of the Italian writer. His translations include Rodari's last—and most controversial—novel on Baron Lamberto. Pinocchio and Lamberto have been among the works chosen to commemorate the 100th anniversary of Gianni Rodari's birth, with a special reprint, a sign of Rodari's magnitude in Poland.

Upon surveying various national libraries, it is evident that some countries, such as France, Germany, Slovakia, Hungary, rely far more on re-translations and re-publications of earlier works, whereas others gained the opportunity to discover Rodari through the lens of different translators, illustrators, and publishing houses. To this end, Giulio Einaudi Publishing House presented a pamphlet for publishers around the world, "100 Gianni Rodari" where it is possible to trace the foreign copyrights sold for Rodari's works in the Einaudi catalogue. The pamphlet is available in a broad range of languages, including lesserknown ones such as Vietnamese and Turkish. This fact could definitely stimulate further research in the children's literature translation practices.

In France, beyond reprints and new editions of Roger Salomon's translations of Rodari's works, the most notable name is Bernard Friot who mainly translated short stories in 2008 and 2010. In Germany, the most recent translations include new editions of "Gelsomino im Lande der Lügner" (Gelsomino in the Land of Liars, in print), "Die Geschäfte des Mister Cat" (Mr. Cat in Business), translated by Giulia Engler in 2019, and "Gutenachtgeschichten am Telefon" (Telephone Tales) by Ulrike Schimming in 2012. In Spain, given the variety of regional languages spoken, the variety of translations has been massive, with works in Castilian, Catalan, Basque, and Galitian. These translations reflect on the multitude of Rodari's literary legacy. In Bulgaria, the "Adventures of the Little Onion" still remains the most reprinted story to date, whereas other works have been newly translated in the $21^{\text {st }}$ century including, "The Ghost Gondola" translated by Ivo Yonkov in 2018. Greece is mostly active in offering its public a wide variety of Rodari's production, especially in the translations by Anna Papastávrou. Her translations from 2003 through 2011 span from short stories to larger novels. Evaluating the online archive of the National Library of Greece, demonstrates the lack of poetry translation into Greek since 2000, a common trend for almost all countries included in this survey. The languages that are still lagging behind in welcoming Rodari's 
works into the $21^{\text {st }}$ century are Arabic (in 2013, only one translation appeared, "Tonino the Invisible"), Estonian (only two translations are available, of which "Telephone Tales" is a reprint of an earlier translation), Latvian (in 2009, Astra Šmite translated "The Grammar of Fantasy", and in 2007 "Telephone Tales"), Norwegian (one translation in 2006, "The Runaway Nose" translated by Steinar Lone), and Swedish ("Telephone Tales" translated in 2003 by Ingrid Börge).

China, Korea, Japan, and Turkey, are among the countries to show a renewed interest in Rodari. Chinese translations revolve around novels and short stories, with different translators and publishing houses. The most active translator into Korean is Lee Hyun Kyung, with books illustrated mainly by Italian artists (e.g. Altan, Sanna, Petrone). These Korean translations show a preference for short stories and novels. The same goes for Japanese translations, mostly attributed to Eiko Sekiguchi (between 2006 and 2013). Turkey presents a variety of translators, among them Eren Cendey, Yelda Gürlek, and Tülin Sadıkoğlu, between 2009 and 2015. The latest translation into Turkish is "Alis'in hikâyeleri" (Alice's Tales) by Filiz Özdem in 2018. In 2011, the American translator, Antony Shugaar introduced his readers to "Lamberto, Lamberto, Lamberto". His newest translation (2020) is Rodari's famous "Telephone Tales", with stunning illustrations by Valerio Vidali.

The above overview suggests that Gianni Rodari is still a much sought-after writer in the $21^{\text {st }}$ century international book market. Rodari's wit and originality, his ability to provide his young readers with alternative visions of the world, his creative and unconventional language, still inspire the young audience today. Book fairs (especially the annual Bologna Children's Book Fair in Italy) prove to be effective in promoting his legacy in countries not familiar with Rodari's work in full. Rodari is known so far as the only Italian children's writer whose literary heritage is very diverse: poetry, short stories, and novels. Such a variety offers unlimited possibilities to the translators, who usually adapt foreign authors to the needs of the specific country. It is evident that short stories and novels comprise the majority of translated works, however poetry has been explored by Spain, Poland, France, Albania, and Russia. This overview is brief attempt to demonstrate the international fame of Gianni Rodari and his permanent presence in international children's literature. More research is needed to capture the full scope of his present-day reach across borders. The celebration of the 100th anniversary of Rodari's birth in 2020 triggered a positive trend toward focused studies dedicated to Italy's beloved Gianni. 


\section{Литература}

\section{Исследования}

Cerutti, Cicala 2002 - Cerutti L., Cicala R. Rodari: le storie tradotte. Novara: Interlinea, 2002.

De Florio 2019 - De Florio G. Emblematic Journeys: Gianni Rodari's Translations in the USSR // Cognition, Communication, Discourse. 2019. No. 18. Pp. 24-33.

Nicewicz-Staszowska - Nicewicz-Staszowska E. «Non vorrei che tu tardassi all'incontro coi bambini polacchi». Sulla fortuna di Gianni Rodari in Polonia. In print.

\section{Claudia Alborghetti}

Università Cattolica del Sacro Cuore; ORCID: 0000-0001-5019-8383

\section{AN OVERVIEW OF GIANNI RODARI'S BOOKS IN TRANSLATION AROUND THE WORLD (2000-2020)}

As the fame of Gianni Rodari reached a new height in 2020 with the celebration of his centennial, this overview of his legacy focuses on the most recent publication of Rodari's works in translation around the world beginning in 2000. His versatility as a writer for children is evident in his entire body of works, his poetry, and his prose. Rodari's translations hardly reflect on the diversity of the genres he had employed in his writings. The outcome of my investigation is the following: Rodari's playfulness in writing, especially in poetry, has found recognition only in Russia, as it proves to be the most prolific country with the mission of spreading Rodari's poetic word to the new generations. Other countries seem to prefer Rodari's prose - his short stories or novels, especially his earlier works such as Cipollino and Telephone Tales. More research has to be done to keep Rodari's popularity thriving, but, as these preliminary findings demonstrate, a renewed interest in the literary legacy of this beloved Italian children's writer is widely spread nowadays, thus promising new poetic translations.

Keywords: Gianni Rodari, Children's literature, translation, Italy 